\title{
Polycyclic aromatic hydrocarbon contamination of Polish smoked fish: Assessment of dietary exposure
}

\author{
Małgorzata Malesa-Ciećwierz $^{1}$ | Olga Szulecka ${ }^{2}$ (D) | Maria Adamczyk ${ }^{1}$
}

${ }^{1}$ Department of Food and Environmental Chemistry, National Marine Fisheries Research Institute (NMFRI), Gdynia, Poland

${ }^{2}$ Department of Fisheries

Economics, National Marine Fisheries

Research Institute (NMFRI), Gdynia, Poland

\section{Correspondence}

Olga Szulecka, Department of Fisheries Economics, National Marine Fisheries Research Institute (NMFRI), 1 Kołtątaja Str., 81-332 Gdynia, Poland.

Email: oszulecka@mir.gdynia.pl

Funding information

Polish Ministry of Science and Higher Education, Grant/Award Number:

Statutory activity $\mathrm{P} 8-3$

\begin{abstract}
The aim of the study was to determine if the smoked fish being produced in Poland complies with the new, stricter limits set for $\mathrm{BaP}$ and PAH4. The effect of sample position in the smoking chamber was also studied. The margin of exposure (MoE) approach was used for assessing the risk of dietary exposure to PAHs from smoked fish products. The study material comprised of sprat, herring, mackerel, and salmon from a fish processing plant equipped with smoking chambers with external smoke generators. None of the smoked fish products studied exceeded the new, stricter limits set for $\mathrm{BaP}$ and PAH4. The MoE indicators far exceed the limit of 10,000 (values lower than this indicate a potential risk to consumer health). The sensory analysis identified significant differences among the products studied that indicate the high quality of cold-smoked salmon fillets and the statistically significant lower quality of a smoked salmon abdominal parts.
\end{abstract}

Practical applications

In 2011 and 2015, the European Commission amended Regulation No. 1881/2006, setting new maximum levels for polycyclic aromatic hydrocarbons in food products in order to protect consumer safety. The currently applicable limits are: for benzo(a) pyrene $-2.0 \mu \mathrm{g} / \mathrm{kg}$ and for the sum of benzo(a)pyrene, benz(a)anthracene, benzo(b) fluoranthene, and chrysene-12.0 $\mu \mathrm{g} / \mathrm{kg}$ in muscle meat of smoked fish and smoked fishery products with the exception of smoked, canned smoked sprat, smoked, and canned smoked Baltic herring $\leq 14 \mathrm{~cm}$, where the limits are, respectively, $5.0 \mu \mathrm{g} / \mathrm{kg}$ and $30.0 \mu \mathrm{g} / \mathrm{kg}$. The presented study was to determine if the sprat, herring, mackerel, and salmon from a fish processing plant equipped with smoking chambers with external smoke generators comply with the new, stricter limits set for BaP and PAH4 by Regulation No. 835/2011 and No. 2015/1125. The results showed that none of 54 smoked fish products that had been examined exceeded the new, stricter limits set for $\mathrm{BaP}$ and $\mathrm{PAH} 4$ and also that changes in PAH4 content depending on the position of the product in the smoking chamber were statistically insignificant, what is important information for processing plants. The sensory analysis indicated the high quality of cold-smoked salmon fillets and the statistically significant lower quality of smoked salmon abdominal parts. 


\section{1 | INTRODUCTION}

Smoking is one of the oldest methods of food preservation known to and used by humankind. Currently, due to the wide range of food preservation methods available, smoking is aimed mainly at giving products a specific taste and aroma that is in high consumer demand and increases their value. The large variety of smoked fish products, both less (smoked sprat) and more expensive (e.g., sliced cold-smoked salmon), satisfies the various tastes and financial means of consumers. This is why smoked fish production remains important. In Europe, smoked fish products represent 15\% of the total quantity of fish on the consumer market (Stołyhwo \& Sikorski, 2005), while in Poland, in 2014, smoked fish production was ranked second in volume after marinated fish (Szostak \& Drożdż, 2015).

Wood smoke contains up to 1,100 chemical compounds (Wilms, 2000) that have different functions and effects in the smoking process. The main smoke components include: phenolic compounds (i.e., guaiacol, cresols, xylenols, and thymol) with strong antimicrobial, fungicidal, and antioxidant properties; carboxylic acids (i.e., formic and acetic acid); and many other compounds (i.e., formaldehyde, acetophenone, acetol, vanillin, and cycloetene) that are desirable for taste and color, and are bactericidal (Ledesma, Rendueles, \& Diaz, 2016). Unfortunately, wood smoke also contains compounds that are undesirable for sensory (phenol, benzol, and acetone) or health reasons. Particular attention has been paid to polycyclic aromatic hydrocarbons (PAHs) which are formed during processes of incomplete combustion and thus occur in wood smoke. The carcinogenic and mutagenic properties of these compounds have been reported by the World Health Organization (WHO, 2006), the International Agency for Research on Cancer (IARC, 2015), the European Scientific Committee on Food (SCF, 2002), the European Food Safety Authority (EFSA), and the US Environmental Protection Agency (EPA).

In 2006, benzo(a)pyrene (BaP) was designated as a marker for the occurrence and effect of PAHs in foods with a maximum permissible level of $5 \mu \mathrm{g} / \mathrm{kg}$ (EC, 2006). However, in 2008, the Panel on Contaminants in the Food Chain (CONTAM) stated that benzo(a) pyrene alone is not a sufficient indicator and advised introducing new maximum levels for the sum of four PAHs (PAH4): benzo(a) pyrene (BaP), benzo(a)anthracene $(\mathrm{BaA})$, benzo(b)fluoranthene $(\mathrm{BbF})$, and chrysene (Chr), while maintaining a separate maximum level for benzo(a)pyrene to ensure comparability of previous and future data (EFSA, 2008). Based on this opinion, the European Commission adopted Regulation No. 835/2011 and No. 2015/1125 (EC, 2011; EU, 2015) amending Regulation No. 1881/2006 (EC, 2006) by setting new maximum levels for PAHs in foodstuffs. The maximum allowable level for $\mathrm{BaP}$ in smoked fish meat and smoked fish products was $5.0 \mu \mathrm{g} / \mathrm{kg}$ of wet weight until August 31, 2014 and $2.0 \mu \mathrm{g} / \mathrm{kg}$ as from September 1, 2014, while the limit for the sum of PAH4 was set at $30.0 \mu \mathrm{g} / \mathrm{kg}$ of wet weight from September 1, 2012 to August 31,2014 and at $12.0 \mu \mathrm{g} / \mathrm{kg}$ as from September 1, 2014. Only for smoked, canned smoked sprat, smoked and canned smoked Baltic herring $\leq 14 \mathrm{~cm}$ limits have not been lowered since September 1 , 2014, and they remain 5.0 and $30.0 \mu \mathrm{g} / \mathrm{kg}$ for $\mathrm{BaP}$ and PAH4, respectively (EC, 2011; EU, 2015).

Unfortunately, according to various researchers (Adeyeye, Oyewole, Obadina, Omemu, \& Omoniyi, 2017; Bykowski et al., 2000; Duedahl-Olesen, Christensen, Højgård, Granby, \& TimmHeinrich, 2010; Essumang, Dodoo, \& Adjei, 2013), these levels are sometimes exceeded. In the monitoring research carried out at the National Marine Fisheries Research Institute in Gdynia (Poland) in 1999, the average BaP content in 27 smoked fish products studied was $8.3 \mu \mathrm{g} / \mathrm{kg}$, while the highest noted BaP content was as high as $111 \mu \mathrm{g} / \mathrm{kg}$ (Bykowski et al., 2000). Since even the average value far exceeds the recently modified maximum permissible BaP level, it is important to determine if fish smoking facilities have been able to improve the safety of their products and to comply with the new, stricter limits set by European Commission Regulation No. 835/2011 and No. 2015/1125 (EC, 2011; EU, 2015). CAC/RCP $68 / 2009$ states that replacing direct smoking (food in a chamber where the smoke is produced) with indirect smoking (smoke developed in an external generator) can significantly reduce contamination in smoked foods. Since modern industrial kilns with external smoke generators can be operated automatically under the controlled conditions to wash the smoke from particles before coming into contact with food, PAH content in smoked products can be reduced (Hokkanen et al., 2018). This is why the main objective of the present study was to determine if smoked fish products processed in modern smoke chambers with an external smoke generator contain permissible levels of $\mathrm{BaP}$ and $\mathrm{PAH} 4$ that meet the criteria of the new EC regulation. The organoleptic properties of fish products smoked in modern smokehouses were also examined, since they strongly affect the consumers' decisions.

\section{MATERIALS AND METHODS}

\section{1 | Study material}

The study material comprised the four fish species of sprat, herring, mackerel, and salmon obtained from a fish processing plant located in the Pomerania region of Poland. The plant has two smoking chambers: smaller-for two and bigger-for three smoking trolleys each equipped with an external smoke generator-constructed respectively in 2012 and 2015. Both chambers were opened from the front and rear (so-called passage chambers), which allowed for the entry of smoking trolleys through the rear door and exit through the front. They were equipped with a control panel, located next to the smoke generator. Both smoking chambers were equipped with a vertical air circulation system. The effect of different sample placement in the smoking chamber (up/down, front/center/back) was studied, as well as differences between samples smoked in the two chambers.

The fish were collected in "sets" comprising a reference (taken from a batch of raw fish before smoking, but after brining), and 
samples from one or two lots of fish after smoking. Both, nonsmoked and smoked fish were transported to the National Marine Fisheries Research Institute (NMFRI) in Gdynia, Poland, for further analyses.

The study material comprised:

- sprat-Sprattus sprattus-11 non-smoked and 19 smoked samples;

- herring-Clupea harengus-8 non-smoked and 10 smoked samples;

- mackerel-Scomber scombrus-6 non-smoked and 11 smoked samples;

- salmon-Salmo salar-10 non-smoked and 14 smoked samples (including five salmon steaks, six samples of smoked salmon abdominal parts, and three smoked salmon fillets).

All the fish were hot-smoked, apart from salmon fillet samples which were cold-smoked. In total, 35 samples of raw material and 54 samples of smoked fish were analyzed.

\section{2 | Methods}

\subsection{1 | Proximate composition analyses}

Moisture, fat, crude protein, and ash content were determined using the AOAC (1990) procedures described by Usydus, Szlinder-Richert, Adamczyk, and Szatkowska (2011).

\subsection{2 | Sensory evaluation}

The evaluation of smoked fish quality was performed using the modified 5-point scale for food product assessment developed by Tilgner (Baryłko-Pikielna \& Matuszewska, 2014; Gawęcka \& Jędryka, 2001). This scale consists of five levels of quality, to each of which a number of points is assigned: very good -5 pts.; good -4 pts.; acceptable-3 pts.; poor-2 pts. disqualifying-1 pt. The scores were rounded to the nearest 0.25 , which permitted identifying differences among samples. Additionally, a weight coefficient was assigned to each parameter that indicated which are the most important in the overal assessment of smoked fish sensory quality.

The following parameters were evaluated (weights in brackets):

- general appearance (0.1);

- $\operatorname{color}(0.1)$;

- gloss (0.1);

- $\operatorname{odor}(0.2)$;

- meat texture (0.15);

- meat color (0.1);

- flavor (0.25).

The results of individual sensory parameter assessments were calculated for each sample as arithmetic means from the scores given by four trained panelists (NMFRI employees), and as weighted arithmetic means for general sensory evaluation comprising all seven parameters.
Arithmetic means were then calculated for each type of smoked product.

\subsection{3 | Polycyclic aromatic hydrocarbons}

\section{Method of determination}

Contents of individual PAHs were determined based on the validated procedure developed at the NMFRI. Validation included determining repeatability and quantitation limit (LOQ), recovery studies-recoveries ranged from $90 \%$ to $100 \%$ for coconut oil (BRC-458), from $81 \%$ to $96 \%$ for fortified olive oil obtained during inter-calibration tests (FAPAS 0630), and from $89 \%$ to $118 \%$ for freeze-dried mussel tissue (NIST 2977). Participation in inter-calibration tests organized by IAEA and FAPAS produced satisfactory results. The limit of quantification was estimated based on corn oil fortification at $0.4 \mathrm{ng} / \mathrm{ml}$ of the final extract.

All the samples, both non-smoked and smoked, were homogenized in a mixer (Multi Processor, Zelmer) and freeze-dried in an Alpha 2-4 LSC freeze-drier (Christ). In the case of sprat, PAH analysis was performed on composite samples of de-headed fish with skin, while in the case of mackerel and herring-fish were filleted and skinned. The salmon-steak, fillet, and abdominal samples were prepared by removing the skin and bones if present. After freezedrying, lipids were extracted with hexane in a Dionex ASE-350 Accelerated Solvent Extractor. The solvent was removed with a rotary evaporator (Heidolph) under reduced pressure. About $0.5 \mathrm{~g}$ of the resultant oil was weighed into graduated test tubes and dissolved in dichloromethane (DCM) so that the final volume was about $4 \mathrm{ml}$. Gel permeation chromatography (GPC) with Waters Envirogel GPC columns $(19 \times 150$ and $19 \times 300 \mathrm{~mm})$ was used for cleaning the extracts with dichloromethane as the mobile phase.

$\mathrm{PAH}$-containing fractions were collected and the resultant eluate was transferred quantitatively into flasks and concentrated with a rotary evaporator. Then the solvent (DCM) was exchanged for acetonitrile (AcCN), and the volume was adjusted to $200 \mu$ l. The final $\mathrm{PAH}$ determinations were conducted with high-performance liquid chromatography with fluorescence detection (HPLC-F) on a MerckHitachi La Chrom System equipped with a PAH Hypersil Column $(250 \times 4.6 \mathrm{~mm}, 5 \mu \mathrm{m})$ and a PAH Drop-in-Guard $(10 \times 4 \mathrm{~mm}, 5 \mu \mathrm{m})$. Oven temperature $30^{\circ} \mathrm{C}$, flow $1 \mathrm{ml} / \mathrm{min}$, and linear gradient $(0-3 \mathrm{~min}$ 50\% AcCN, 3-50 min: 50\%-100\% AcCN, 50-58 min 100\% AcCN) were used. The excitation and emission wavelengths $\left(\lambda_{\text {ex/em }}\right)$ were as follows: $270 / 390$ for chrysene and benzo(a)anthracene; 305/430 for benzo(a)pyrene and benzo(a)anthracene. Individual PAHs were identified and quantified based on retention times and 6-point calibration curves $\left(r^{2}>0.999\right)$ obtained from prepared standard solutions (Z-013-17 PAH Solution Mix, Accustandard). All the solvents used were purchased from Merck.

The quality assurance of the determinations was ensured with a parallel analysis of standard reference material 1647d (NIST) and procedural blank samples. All sample analyses were performed in duplicate. 


\section{Health risk assessment}

The margin of exposure (MoE) approach was used for assessing the risk of dietary exposure to PAHs from smoked fish products. The $\mathrm{MoE}$ was calculated by dividing the $\mathrm{BMDL}_{10}$ (benchmark dose lower confidence limit $10 \%$ ) value by the average daily $\mathrm{BaP}$ or $\mathrm{PAH} 4$ intake from smoked fish. The $\mathrm{BMDL}_{10}$ value estimates the dose causing no more than $10 \%$ cancer incidence in rodents with a $95 \%$ confidence interval. According to EFSA (2008), a $\mathrm{BMDL}_{10}$ of 0.07 and $0.34 \mathrm{mg}$ / kg b.w. per day, respectively, for $\mathrm{BaP}$ and $\mathrm{PAH} 4$, should be used as the reference values in MoE calculations. Daily consumption of smoked fish in Poland was assessed based on data presented in the Seafood Study (Pettersen, 2015). MoE values lower than 10,000 indicate a potential hazard to consumer health.

\subsection{4 | Statistical analysis}

Statistical analysis was performed using Statistica, version 10.0 (StatSoft). To assess the significance of changes occurring during the smoking process and the differences among samples smoked under different conditions, the independent sample $t$-test was performed, and $p<0.05$ was considered statistically significant. To assess the significance of differences among sensory evaluation results and among the PAH4 profiles of different smoked products, hierarchical cluster analysis with agglomeration as a grouping method was used.

\section{RESULTS AND DISCUSSION}

\section{1 | Proximate composition}

The average contents of water, ash, crude fat, and protein of fish/ fish parts before and after smoking are presented in Table 1.

Among the non-smoked fish tested, the highest water content was found in herring-it ranged from $65.6 \%$ to $77.1 \%$, and was accompanied by the lowest fat content (from $3.8 \%$ to $15.5 \%$, at an average of $10.1 \%)$. The lowest water content was observed in salmon abdominal parts (from $36.2 \%$ to $48.8 \%$ ) and was accompanied by the highest fat content that ranged from $36.0 \%$ to $52.8 \%$ (46.3\% on average).

The highest raw material protein content was found in salmon fillets and the lowest in salmon abdominal parts from $21.3 \%$ to $22.3 \%$ and from $8.6 \%$ to $12.4 \%$, respectively. The ash content was also the highest in the salmon fillets $(4.8 \%-6.3 \%)$. This was probably because of the high salt content; the salmon fillets were the only raw material subjected to dry salting instead of brining, and this process lasted for as long as $45 \mathrm{hr}$. The lowest ash contents were recorded in mackerel (from $1.4 \%$ to $2.0 \%$, at an average of $1.7 \%$ ) and in salmon abdomens (1.8\%), although the values recorded for the latter varied within fairly wide limits (from $0.9 \%$ to $2.4 \%$ ).

Smoking resulted in significant $(p<0.05)$ reductions in moisture content in all of the products examined except for smoked mackerel. The highest water decrease was observed in salmon abdominal parts at an average of $20.1 \%$ of the initial value. Moisture losses in salmon steaks, salmon fillets, sprat, and herring averaged $11.9 \%, 11.6 \%, 7.9 \%$, and $7.3 \%$, respectively. The wet weight of smoked mackerel generally reflected the values of the non-smoked fish with an average reduction in water content of $0.2 \%$. However, the moisture content of nonsmoked mackerel was quite low (52.4\%-56.3\%). These relatively low values were probably the result of the long $(165 \mathrm{~min})$ brining process.

A decrease in moisture content is important since it reduces microbial activity and extends product shelf life. Industrial outlines for "smoked finished products" recommend a water content lower than 65\% (Cardinal et al., 2001). The water content obtained for all the products examined, except smoked herring, in which average water content exceeded slightly the recommended value $(65.2 \%$ on average), met this recommendation.

Fish drying is closely associated with the heating process that occurs during smoking, and it is also related to the fat content of the smoked product (Ünlüsayin, Süleyman, \& Gulyavuz, 2001). This is why the higher water loss during the process, the higher increase in fat percentage was observed in the studied samples (Figure 1).

\begin{tabular}{|llllll|}
\hline Fish samples & Condition & Water (\%) & Fat (\%) & Protein (\%) & Ash (\%) \\
\hline Sprat & Non-smoked & $65.8 \pm 5.2^{\mathrm{a}}$ & $16.2 \pm 4.8$ & $16.0 \pm 0.5^{\mathrm{a}}$ & $2.2 \pm 0.4^{\mathrm{a}}$ \\
& Smoked & $60.6 \pm 3.6^{\mathrm{b}}$ & $17.8 \pm 4.1$ & $18.9 \pm 0.6^{\mathrm{b}}$ & $2.8 \pm 0.2^{\mathrm{b}}$ \\
\hline Herring & Non-smoked & $70.3 \pm 4.3^{\mathrm{a}}$ & $10.1 \pm 4.8$ & $17.5 \pm 0.8^{\mathrm{a}}$ & $2.0 \pm 0.3^{\mathrm{a}}$ \\
& Smoked & $65.2 \pm 5.1^{\mathrm{b}}$ & $11.6 \pm 4.9$ & $20.8 \pm 1.7^{\mathrm{b}}$ & $2.4 \pm 0.3^{\mathrm{b}}$ \\
\hline Mackerel & Non-smoked & $54.7 \pm 1.4$ & $26.8 \pm 1.9$ & $16.8 \pm 0.7^{\mathrm{a}}$ & $1.7 \pm 0.2$ \\
& Smoked & $54.8 \pm 1.9$ & $25.5 \pm 2.4$ & $18.0 \pm 0.7^{\mathrm{b}}$ & $1.9 \pm 0.2$ \\
\hline Salmon fillets & Non-smoked & $60.2 \pm 0.3^{\mathrm{a}}$ & $12.7 \pm 1.2^{\mathrm{a}}$ & $21.7 \pm 0.5^{\mathrm{a}}$ & $5.5 \pm 0.8$ \\
& Smoked & $53.2 \pm 1.7^{\mathrm{b}}$ & $22.4 \pm 2.0^{\mathrm{b}}$ & $20.6 \pm 0.5^{\mathrm{b}}$ & $3.9 \pm 0.7$ \\
\hline Salmon steaks & Non-smoked & $67.0 \pm 2.7^{\mathrm{a}}$ & $12.0 \pm 2.8^{\mathrm{a}}$ & $18.1 \pm 0.1^{\mathrm{a}}$ & $2.7 \pm 0.3$ \\
& Smoked & $59.0 \pm 1.0^{\mathrm{b}}$ & $16.7 \pm 1.1^{\mathrm{b}}$ & $21.8 \pm 0.4^{\mathrm{b}}$ & $2.8 \pm 0.6$ \\
\hline Salmon abdomens & Non-smoked & $41.2 \pm 6.0^{\mathrm{a}}$ & $46.3 \pm 8.2$ & $10.5 \pm 1.7$ & $1.8 \pm 0.6$ \\
& Smoked & $32.9 \pm 6.7^{\mathrm{b}}$ & $52.0 \pm 9.1$ & $13.2 \pm 2.6$ & $2.1 \pm 0.6$ \\
\hline
\end{tabular}

TABLE 1 Average proximate composition of fish samples before and after smoking

Note. The superscript notations ${ }^{\mathrm{a}, \mathrm{b}}$ denote significant differences $(p<0.05)$ among smoked and non-smoked fish samples. 
Nevertheless, changes in fat content were statistically significant $(p<0.05)$ only in salmon fillets and salmon steaks at $76.4 \%$ and $39.2 \%$ of initial values, respectively. Mackerel was the only product in which a slight decrease in fat content (less than $5 \%$, on average) was observed. The lack of significant fat loss is beneficial for nutritional reasons because the fat in fish and fish products contains $\mathrm{n}-3$ polyunsaturated fatty acids that are important for human health (Ruxton, Reed, Simpson, \& Millington, 2007).

The average protein content in the smoked samples tested varied from $13.2 \%$ in salmon abdominal parts to $21.8 \%$ in salmon steaks. The products with the highest protein contents (above 20\%) were salmon steaks, herring, and salmon These results, which suggest that smoked fish products are good sources of protein, are similar to those published by Usydus, Szlinder-Richert, and Adamczyk (2009), although the values determined were slightly lower in sprat and mackerel and higher in salmon fillets and herring.

The average ash content in the smoked fish products ranged from $1.9 \%$ in mackerel to $3.9 \%$ in salmon fillets. In all the hot-smoked samples examined, the ash percentage increased, but the change was statistically significant only in sprat and herring. The average ash percentage in cold-smoked salmon fillets decreased, but not significantly.

\section{2 | Sensory evaluation}

The results of the sensory evaluation of smoked products ranged from 3 to 4 points, which correspond to "acceptable" and "good," respectively (Figure 2), while most of the products evaluated were closer to the "good" evaluation. Product flavor received the lowest evaluation among all of the sensory parameters studied. The mean evaluation of the various parameters ranged from 3.70 to 3.92 points and increased as follows: flavor < gloss < meat texture < general appearance $<$ skin color $<$ meat color $<$ odor. The analysis of Figure $2 a$ may lead to the conclusion that salmon abdominal parts received the lowest evaluations in almost all of the parameters examined, while salmon fillets received the highest. The average sensory evaluation of studied products decreased as follows: salmon fillets $>$ mackerel $>$ herring $>$ sprat $>$ salmon steaks $>$ salmon abdominal parts. These results confirm popular consumer opinion regarding the high quality of smoked salmon. Still, not only salmon fillets but also smoked mackerel received high mean evaluations, varying within narrow ranges (Figure $2 b$ ). The high quality of these products is confirmed in the Seafood Study (Pettersen, 2015), according to which mackerel and salmon fillets are the most popular and most highly valued smoked products in Poland. Salmon abdominal parts have higher fat contents than the other products and that is why they are not as highly valued by consumers who prefer smoked fish with a lower fat content.

Cluster analysis, which was performed to estimate the statistical significance of differences in sensory evaluation parameters, indicated that there were two clearly distinguishable similarity groups. One comprised the smoked salmon abdominal parts, while the second included all of the other products. This is evidence of the significantly lower sensory quality of the salmon abdomens. Independent samples $t$-tests $(p<0.05)$ indicated that these differences referred mainly to such sensory parameters as meat texture, meat color, and flavor.

\section{3 | Polycyclic aromatic hydrocarbons}

\subsection{1 | PAH levels and profiles in non-smoked and smoked fish products}

Of all the non-smoked fish tested, neither herring nor mackerel contained BaP levels above the method's quantification limit. Among all the salmon samples (abdomens, fillets, and steaks), only one salmon
FIGURE 1 The relationship between water loss and the increase in fat percentage observed during smoking

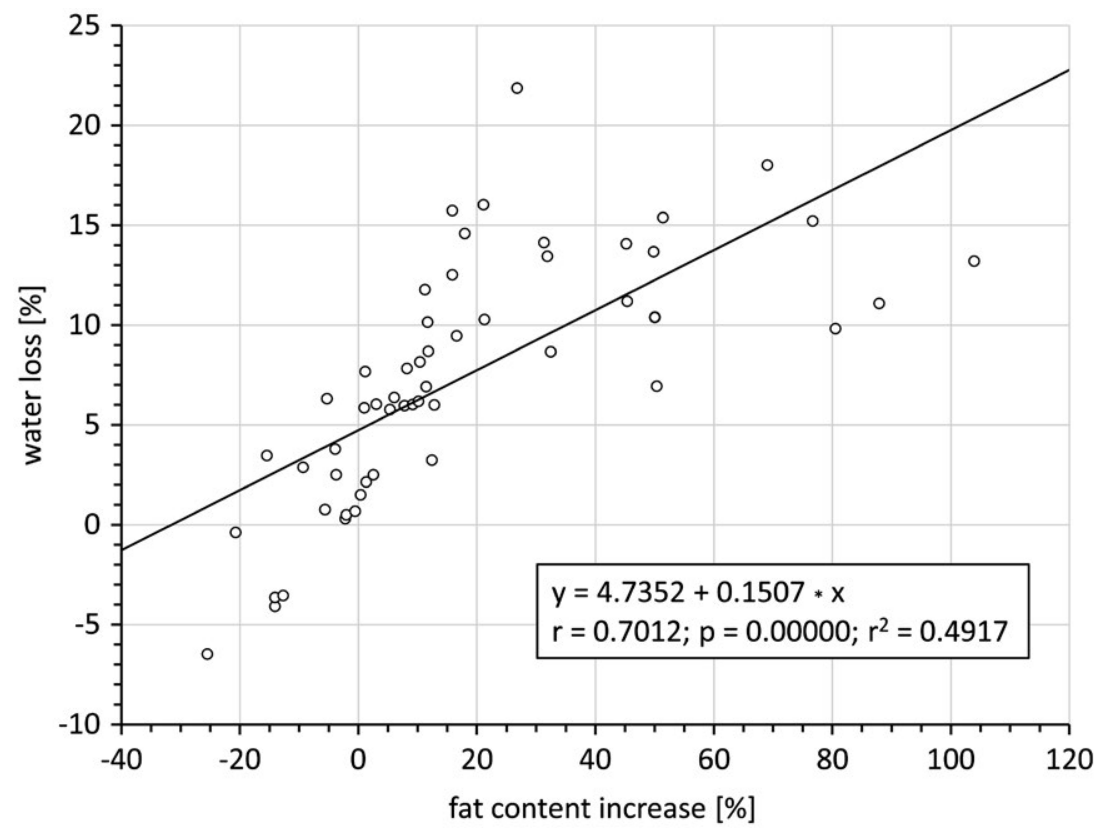


(a)

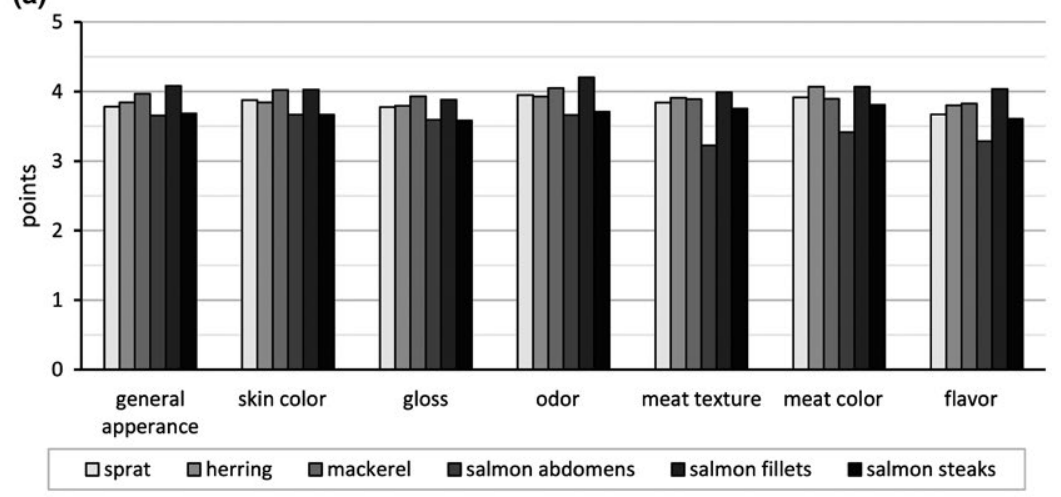

(b)

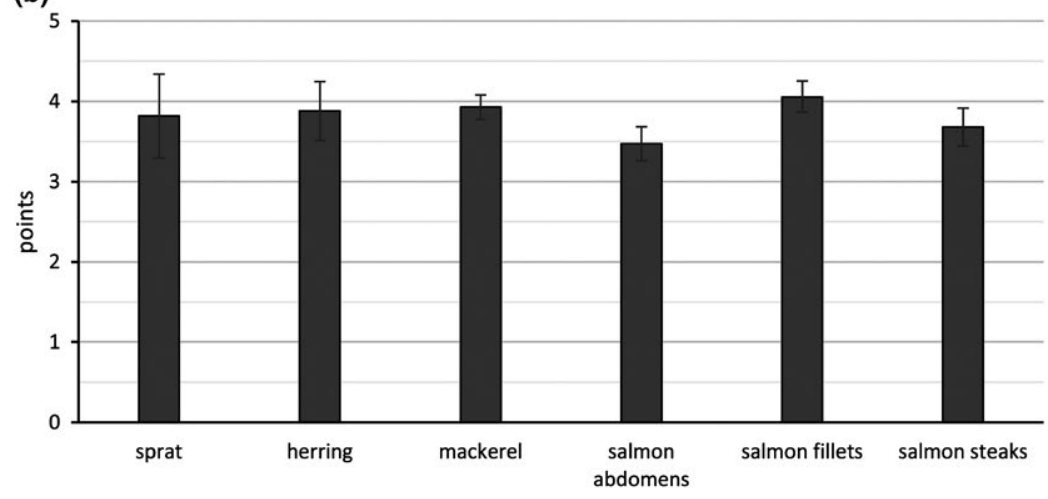

(c)

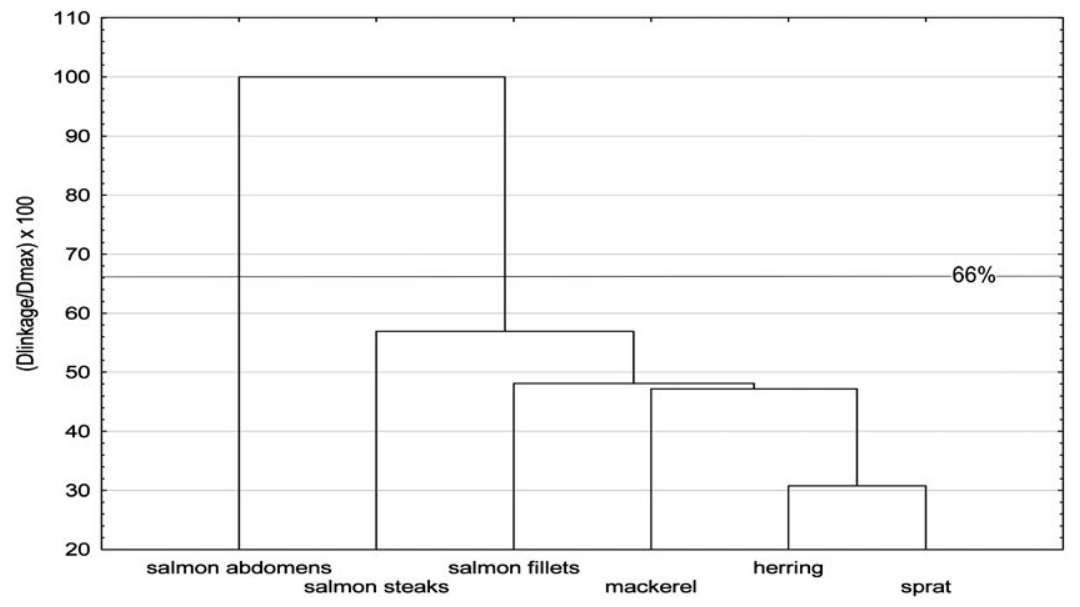

FIGURE 2 Sensory evaluation of smoked products $(a, b)$ and cluster analysis tree diagram depicting similarity in sensory evaluation (c). In b bars represent average scores, taking into account all the sensory parameters; whiskers-minimum and maximum steak contained $\mathrm{BaP}$ at a level slightly exceeding LOQ. On the other hand, nearly half of the raw sprat samples contained quantifiable amounts of $\mathrm{BaP}$ that ranged quite widely from 0.05 to $0.36 \mu \mathrm{g} / \mathrm{kg}$. Generally, benzo(a)pyrene was the least frequently occurring of the four PAHs studied; it was found only in $17 \%$ of the non-smoked samples. The edible parts of fish from uncontaminated water generally do not contain detectable amounts of BaP (Rainio, Linko, \& Routsila, 1986). Apart from the question of water pollution, PAHs are not bioaccumulated in fish muscle as they are rapidly metabolized in the liver into more hydrophilic substances which are secreted into the bile and stored in the gall bladder (Ariese et al., 1993). Still, benzo(a) anthracene, chrysene, and benzo(b)fluoranthene proved to be more prevalent than benzo(a)pyrene and were found, respectively, in $66 \%, 89 \%$, and $34 \%$ of non-smoked samples. Only in 3 of 54 raw fish samples studied (one mackerel, one salmon abdomen, and one salmon fillet) all four of the PAHs tested were below the LOQ. Sprat had the highest average levels of both $\mathrm{BaP}(0.09 \mu \mathrm{g} / \mathrm{kg})$ and PAH4 $(0.56 \mu \mathrm{g} / \mathrm{kg}$ ) (Table 2). The highest individual content of BaP and $\mathrm{PAH} 4$ among non-smoked fish was also observed in sprat samples $(0.36 \mu \mathrm{g} / \mathrm{kg}$ and $1.58 \mu \mathrm{g} / \mathrm{kg}$, respectively). The fact that the contents of the PAHs tested were the highest in sprat could be attributed to the analytical procedure. The sprat samples were analyzed together with the skin, that is a natural barrier to the PAHs present in the environment, and may thus contain higher levels of these substances. Generally, the results obtained for non-smoked fish are consistent with conclusions presented by Stołyhwo and Sikorski (2005) who state that fish can naturally contain small amounts of various PAHs absorbed from the environment. 
TAB LE 2 BaP and PAH4 content in fish samples before and after smoking

\begin{tabular}{|c|c|c|c|c|c|c|c|}
\hline \multirow[b]{2}{*}{ Fish product } & \multirow[b]{2}{*}{ Condition } & \multicolumn{3}{|c|}{$\mathrm{BaP}(\mu \mathrm{g} / \mathrm{kg})$} & \multicolumn{3}{|c|}{ PAH4 ( $\mu \mathrm{g} / \mathrm{kg})$} \\
\hline & & Average & Min & Max & Average & Min & Max \\
\hline \multirow[t]{2}{*}{ Sprat } & Non-smoked & 0.09 & nd & 0.36 & 0.56 & 0.06 & 1.58 \\
\hline & Smoked & 0.28 & 0.10 & 0.89 & 3.05 & 1.23 & 6.77 \\
\hline \multirow[t]{2}{*}{ Herring } & Non-smoked & nd & & & 0.13 & 0.06 & 0.22 \\
\hline & Smoked & 0.14 & 0.06 & 0.23 & 1.69 & 0.76 & 2.91 \\
\hline \multirow[t]{2}{*}{ Mackerel } & Non-smoked & nd & & & 0.11 & nd & 0.25 \\
\hline & Smoked & 0.06 & nd & 0.20 & 0.89 & 0.10 & 1.75 \\
\hline \multirow[t]{2}{*}{ Salmon filets } & Non-smoked & nd & & & 0.12 & nd & 0.21 \\
\hline & Smoked & 0.20 & 0.14 & 0.30 & 1.70 & 1.32 & 2.24 \\
\hline \multirow[t]{2}{*}{ Salmon steaks } & Non-smoked & 0.01 & nd & 0.04 & 0.25 & 0.15 & 0.40 \\
\hline & Smoked & 0.16 & 0.12 & 0.22 & 2.20 & 1.94 & 2.61 \\
\hline \multirow{2}{*}{$\begin{array}{l}\text { Salmon } \\
\text { abdomens }\end{array}$} & Non-smoked & nd & & & 0.17 & nd & 0.40 \\
\hline & Smoked & 0.11 & nd & 0.16 & 2.67 & 0.80 & 4.55 \\
\hline
\end{tabular}

The smoking process, regardless of the smoking chamber used or the placement of the fish in it, resulted in a statistically significant increase in all the PAHs tested. The exception was BaP, which did not increase to levels that allowed quantitative determination in 7 of 11 smoked mackerel samples and in 1 of 6 salmon abdomens. DuedahlOlesen et al. (2010) also presented results according to which BaP was not detected in any of the indirectly smoked mackerel samples they examined.

Similarly, as before smoking, the highest mean contents of $\mathrm{BaP}$ and $\mathrm{PAH} 4$ of all the smoked samples were noted in sprat at $0.28 \mu \mathrm{g} / \mathrm{kg}$ and $3.05 \mu \mathrm{g} / \mathrm{kg}$, respectively. The mean content of $\mathrm{BaP}$ in the smoked products decreased as follows: sprat > salmon fillets $>$ salmon steaks $>$ herring $>$ salmon abdomens $>$ mackerel. In the case of $\mathrm{PAH} 4$, the sequence was slightly different: sprat > salmon abdomens $>$ salmon steaks $>$ salmon fillets $=$ herring $>$ mackerel. Salmon abdomens shifted toward the top of the series because of the higher content of four-ring PAHs ( $\mathrm{BaA}$ and $\mathrm{Chr}$ ). The highest $\mathrm{PAH} 4$ content in sprat most probably stemmed from the skin included in the samples tested (the decision for using this approach was guided by the fact that most smoked sprat is consumed with the skin). In turn, the greatest variability in results, which was also observed in sprat, could have stemmed from incomplete control of reactions inside smoking chambers, despite the electronically steered process, or from size differences among the smoked fish, resulting in different shares of skin in the composite samples (the smaller the fish the more developed the surface is). The lowest contents of $\mathrm{BaP}$ and $\mathrm{PAH} 4$ noted in mackerel can be explained by the fact that mackerel is smoked with the skin, which is later removed. At the same time, mackerel carcass is thicker than the other smoked fish tested. These two factors result in smaller penetration of PAHs into mackerel muscle tissues. The experimental work conducted for the present study, in which smoked mackerel was skinned and then the PAHs were determined in the smoked fish meat and skin, confirmed these conclusions. In comparison to the meat, the skin contained 38 times more $\operatorname{BaP}(3.45 \mu \mathrm{g} / \mathrm{kg}$ vs. $0.09 \mu \mathrm{g} / \mathrm{kg})$ and 26 times more PAH4 (24.48 $\mu \mathrm{g} / \mathrm{kg}$ vs. $0.94 \mu \mathrm{g} / \mathrm{kg})$. Statistically significant higher percentage shares of $\mathrm{BaP}$ in the total $\mathrm{PAH} 4$ contents were noted in the skin at the expense of significantly lower percentages of chrysene. This finding suggests that the skin is a stronger barrier against five-ring BaP than against smaller, four-ring chrysene. This conclusion could also explain the fact that the upward trends of $\mathrm{BaP}$ and $\mathrm{PAH} 4$ content in different forms of smoked salmon (steaks, fillets, and abdomens) do not coincide. As the percentage of surface area covered by the skin is unequal, different shares of $\mathrm{BaP}$ and $\mathrm{PAH} 4$ are eliminated during skinning. Since the BaP toxic equivalency factor is 100 times higher than that of chrysene (U.S. EPA, 1993), removing the skin before the consumption of smoked fish should be strongly recommended.

The mean percentage shares of each of the PAH4 hydrocarbons in the smoked fish products tested is presented in Figure 3a. Chrysene was the dominant of the four PAHs in all of the products tested. In the case of herring, mackerel, salmon abdomens, salmon fillets, and salmon steaks the percentage shares of the individual $\mathrm{PAH}$ s decreased as follows: $\mathrm{Chr}>\mathrm{BaA}>\mathrm{BbF}>\mathrm{BaP}$. Akpambang et al. (2009) and Zachara, Gałkowska and Juszczak (2017) report similar results, respectively, for smoked mackerel and salmon. Only in sprat was the order slightly different with a higher percentage share of $\mathrm{BaP}$ than $\mathrm{BbF}$. This could have stemmed from the skin in the sprat samples, in which the percentage share of $\mathrm{BaP}$ is higher than in smoked fish meat, as the experiment described previously demonstrated. The difference in the PAH4 profiles of sprat and the other products, however, is not statistically significant. A cluster analysis (Figure $3 b$ ) shows that there are three distinguishable groups of PAH4 profiles similarity: the first includes sprat, herring, mackerel, and salmon steaks; the second-salmon abdomens; the third-salmon fillets. The analysis of Figure 3a indicates that salmon abdomens had the highest percentage share of four-ring hydrocarbons (particularly of chrysene) and the lowest share of five-ring hydrocarbons. The situation was the reverse for salmon fillets. 
(a)

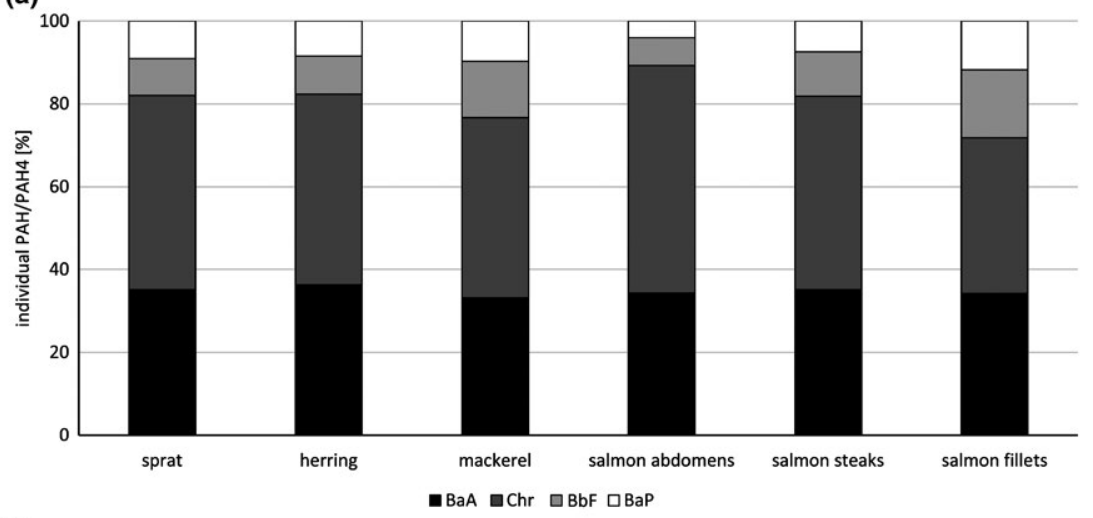

(b)

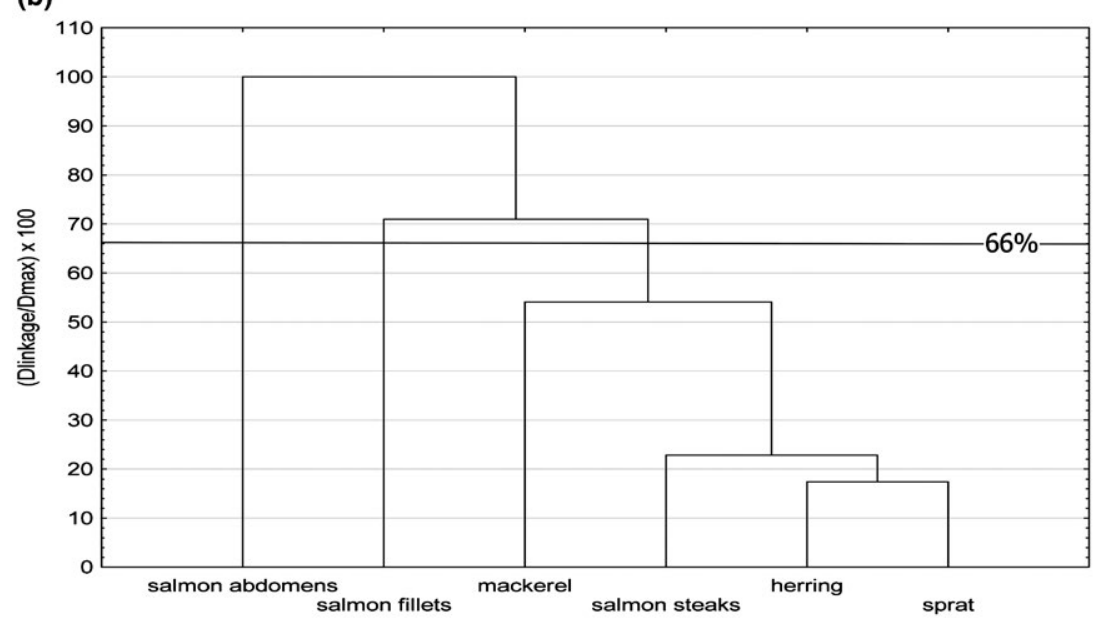

FIGURE 3 The percentage contributions of individual PAHs to $\mathrm{PAH} 4$ in the smoked fish products (a) and cluster analysis tree diagram depicting the statistical significance of changes in $\mathrm{PAH} 4$ profiles (b)
The contents of PAH4 in fish smoked in different smoking chambers (smaller-produced in 2012 and bigger-manufactured in 2015) and in different positions in the chambers were compared (Figure 4). Despite the fact that differences in the mean values are in some cases (e.g., sprat smoked in different chambers) fairly large, the variability of the results causes that these differences are not statistically significant. Pöhlmann, Hitzel, Schwägele, Speer, and Jira (2013) report the occurrence of small differences in $\mathrm{PAH} 4$ content in frankfurter smoked sausages depending on the position in the smoking chamber (front, center-front, center-back, and back), but they did not evaluate the statistical significance of these differences. Roseiro, Gomes, and Santos (2011), in turn, found that placement in the smoking chamber led to differences in PAH content in traditionally smoked Portuguese meat products; however, these differences were most probably caused by the construction of the smoking chamber that resulted in uneven smoke distribution.

\subsection{2 | Health risk assessment}

None of the 54 tested fish products that were smoked in smoking chambers with external smoke generators exceeded the new, stricter limits for $\mathrm{BaP}$ and $\mathrm{PAH} 4$ content. The mean $\mathrm{BaP}$ content in the smoked fish products ranged from $3 \%$ (mackerel) to $10 \%$ (salmon fillets) of the maximum level of $2 \mu \mathrm{g} / \mathrm{kg}$ for all of the products except sprat, for which the limit is $5 \mu \mathrm{g} / \mathrm{kg}$. Slightly higher values, but still within permissible limits were noted in the case of $\mathrm{PAH} 4$. These ranged from
$7 \%$ (mackerel) to $22 \%$ (salmon abdomens) of the maximum level set at $12 \mu \mathrm{g} / \mathrm{kg}$ for all products except for sprat, for which the limit is $30 \mu \mathrm{g} /$ $\mathrm{kg}$. Not only the mean but also maximum contents of $\mathrm{BaP}$ and PAH4 were within the limits set by the European Union (EC, 2011; EU, 2015). The highest BaP content determined was $0.89 \mu \mathrm{g} / \mathrm{kg}$, which was $18 \%$ of the maximum level. The result closest to the limit set for PAH4 was observed in a sample of salmon abdominal parts and reached $4.55 \mu \mathrm{g}$ $\mathrm{PAH} 4 / \mathrm{kg}$ (i.e., 38\% of the maximum level). Stołyhwo and Sikorski (2005) report that fish meat smoked in modern, automated smoking chambers in which the smoke is generated under controlled conditions contains about $0.1 \mu \mathrm{g} \mathrm{BaP} / \mathrm{kg}$. The mean value determined in the present study was slightly higher, reaching $0.18 \mu \mathrm{g} / \mathrm{kg}$; still it proves that fish smoked in chambers with external smoke generators meet the criteria set forth in current regulations concerning PAH levels.

The health risk resulting from consuming $\mathrm{PAH}$ s with smoked fish was assessed by calculating the MoE. Two variants were considered-taking into account the mean and the highest levels of $\mathrm{PAH}$ determined (Table 3). Data on fish consumption in Poland (0.7 kg annually) is based on Seafood Study (Pettersen, 2015). Calculating MoE indicators demonstrated that they exceed (by 150 times even in the least advantageous variant) the value of 10,000 , below which they indicate a potential risk to consumer health. Considering that information regarding the $\mathrm{PAH}$ risk associated with smoked fish consumption frequently appears in the mass media, the daily consumption of these fish was calculated so that the MoE would reach the borderline limit of 10,000 (Table 4). 


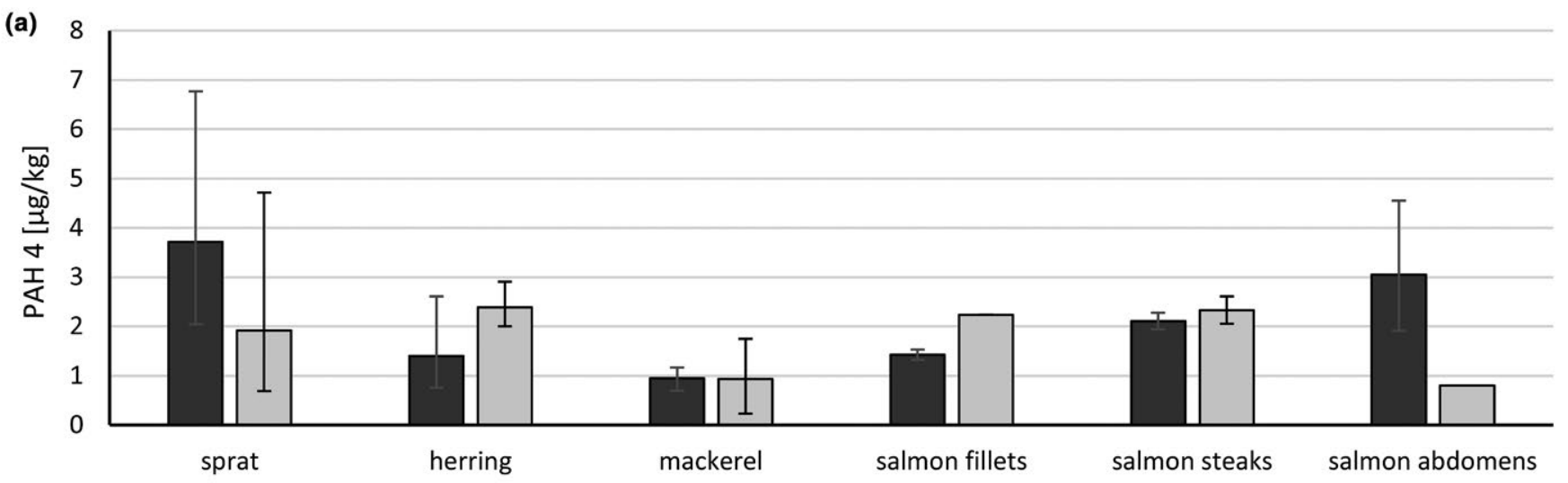

2-trolley chamber $\square$ 3-trolley chamber

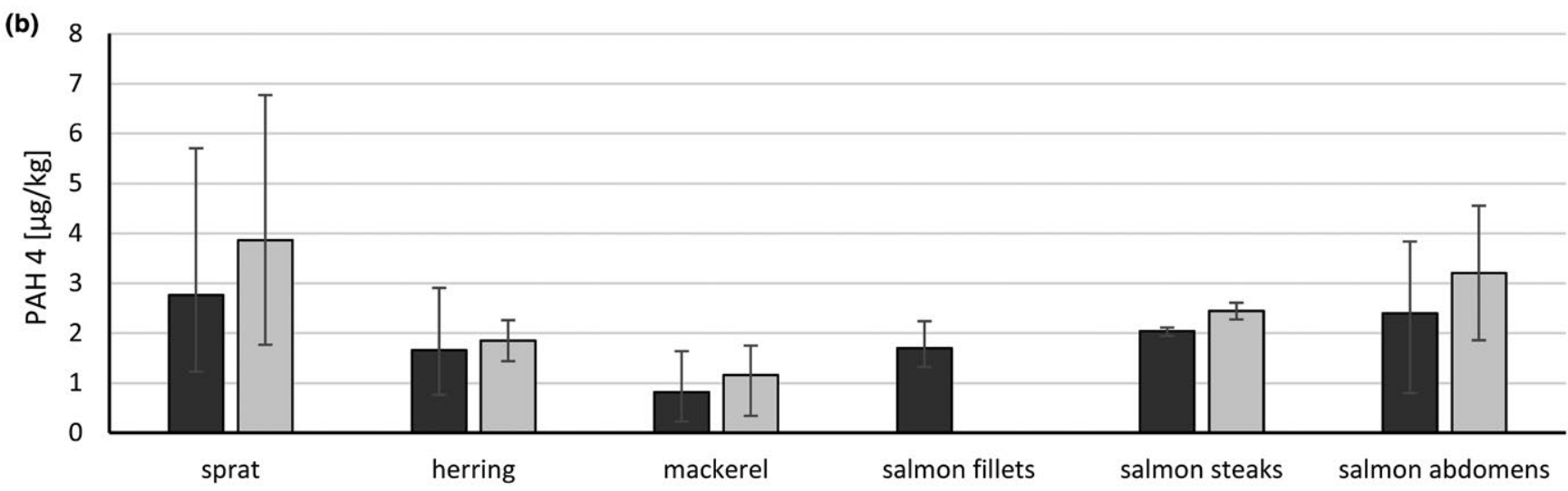

higher position $\quad$ lower position

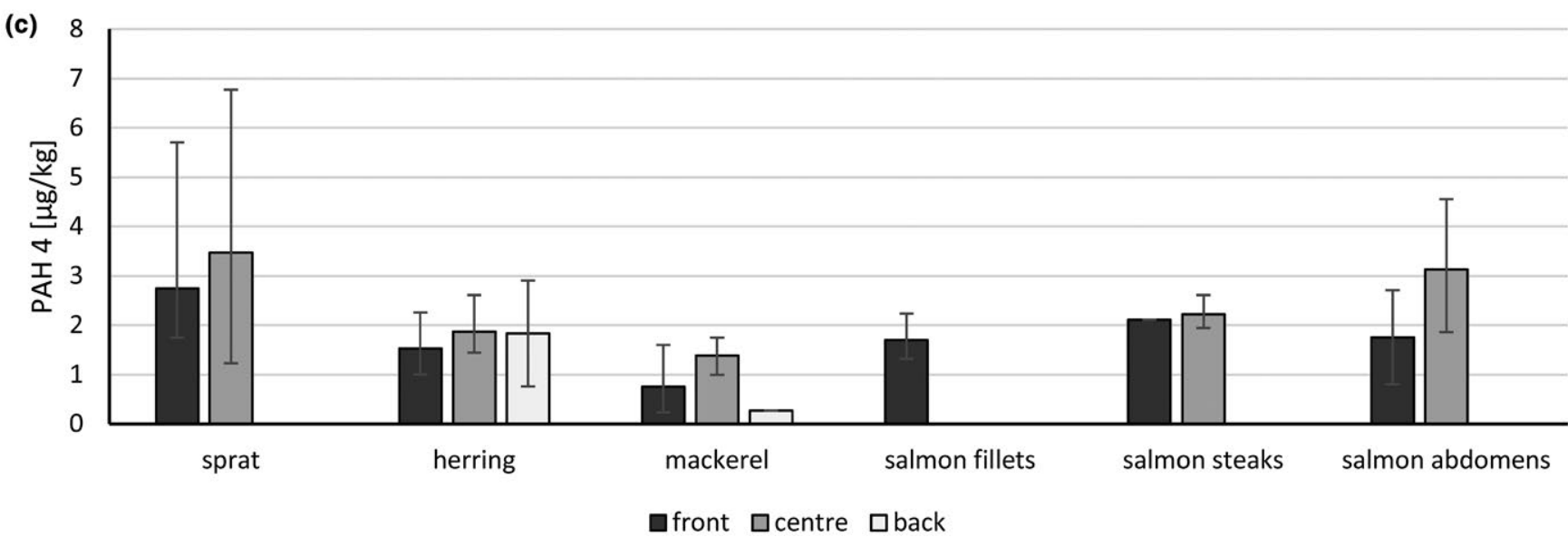

FIGURE 4 Contents of PAH4 in smoked fish depending on the smoking chamber used (a) or position of the product in the chamber (b and c). Bars represent average values; whiskers-minimum and maximum

The calculations based on the mean PAH values determined in the present study, indicated that to achieve MoE of 10,000 , the daily consumption of smoked fish would have to exceed $2.3 \mathrm{~kg}$ with regard to $\mathrm{BaP}$ or nearly $1 \mathrm{~kg}$ with regard to the sum of $\mathrm{BaA}$, $\mathrm{Chr}, \mathrm{BbF}$, and $\mathrm{BaP}$. If the consumer always consumed fish with the highest levels of $\mathrm{BaP} / \mathrm{PAH} 4$ determined, then to reach the $\mathrm{MoE}$ of 10,000 , daily smoked fish consumption would have to be $470 \mathrm{~g}$ (with regard toBaP) and $300 \mathrm{~g}$ (with regard toPAH4). Since it is difficult to imagine such high daily consumption, one can conclude that consuming fish that has been smoked in modern, automated smoking chambers does not pose a risk to consumers. Since some research indicates that $\mathrm{PAH}$ levels are higher in products smoked in traditional smokehouses (Adeyeye et al., 2016; Duedahl-Olesen et al., 2010; Wretling, Eriksson, Eskhult, \& Larsson, 2010), it would be advisable to estimate the risk posed by these types of products especially since their popularity is on the rise. 
TAB LE 3 Assessment of the risk from PAHs present in smoked fish

\begin{tabular}{|c|c|c|c|c|c|c|c|}
\hline & $\begin{array}{l}\text { Average } \\
(\mu \mathrm{g} / \mathrm{kg})\end{array}$ & $\begin{array}{l}\text { Max } \\
(\mu \mathrm{g} / \mathrm{kg})\end{array}$ & $\begin{array}{l}\mathrm{BMDL}_{10} \\
\text { (mg/kg/day) }\end{array}$ & $\begin{array}{l}\text { Average daily human } \\
\text { exposure }^{\text {a }} \text { (ng/kg bw/day) }\end{array}$ & $\mathrm{MoE}_{\mathrm{av}}$ & $\begin{array}{l}\text { Max daily human exposure } \\
\text { (ng/kg bw/day) }\end{array}$ & $\mathrm{MoE}_{\max }$ \\
\hline $\mathrm{BaP}$ & 0.18 & 0.89 & 0.07 & 0.006 & $11,666,667$ & 0.030 & $2,333,333$ \\
\hline
\end{tabular}

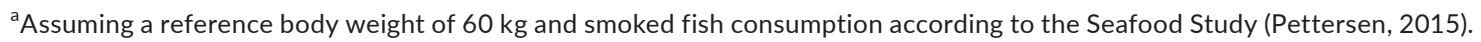

TA B LE 4 Consumption of smoked fish necessary to obtain MoE values indicating a potential concern for consumer health (calculated for a body weight of $60 \mathrm{~kg}$ )

\begin{tabular}{|c|c|c|c|c|c|c|c|}
\hline & $\begin{array}{l}\text { Average } \\
(\mu \mathrm{g} / \mathrm{kg})\end{array}$ & $\begin{array}{l}\operatorname{Max}(\mu \mathrm{g} / \\
\mathrm{kg})\end{array}$ & $\begin{array}{l}\mathrm{BMDL}_{10} \\
\text { (mg/kg/day) }\end{array}$ & MoE & $\begin{array}{l}\text { Daily human exposure } \\
\text { (ng/kg bw/day) }\end{array}$ & Consumption ${ }^{\mathrm{a}}$ (g/day) & Consumption $^{\mathrm{b}}$ (g/day) \\
\hline $\mathrm{BaP}$ & 0.18 & 0.89 & 0.07 & 10,000 & 7 & 2,350 & 470 \\
\hline
\end{tabular}

${ }^{\mathrm{a}}$ Assuming average BaP/PAH4 content. ${ }^{\mathrm{b}}$ Assuming maximum BaP/PAH4 content.

\section{4 | CONCLUSIONS}

The sensory analysis identified significant differences among the products studied that indicate the high quality of cold-smoked salmon fillets and the statistically significantly lower quality of smoked salmon abdominal parts. However, the products examined generally obtained scores between "acceptable" and "good." Among the 54 smoked fish products studied, none exceeded the new, stricter limits set for BaP and PAH4 by European Commission Regulation No. 835/2011 and No. 2015/1125 (EC, 2011; EU, 2015). The calculation of MoE indicators confirmed that smoked fish consumption poses a negligible risk of $\mathrm{PAH}$ exposure, at least when the products are processed in modern, automatic chambers equipped with external smoke generators. Whether or not the same is true for products smoked in traditional smokehouses should be investigated. No statistically significant changes in $\mathrm{PAH} 4$ content were noted with regard to the position of the product in the smoking chamber.

\section{ACKNOWLEDGMENTS}

This research project was financed by the Polish Ministry of Science and Higher Education with funds for scientific studies (Statutory activity P8-3). The funding source was not involved in study design, in the collection and interpretation of data nor in the writing of the article. The authors would like to thank Professor Joanna SzlinderRichert for the preliminary review of the manuscript and her valuable suggestions. The authors also would like to thank dr Bogusław Pawlikowski, Kamila Kozieł, and Dorota Janiszewska for helping in sensory evaluation of analyzed products.

\section{CONFLICT OF INTEREST}

The authors have declared no conflicts of interest for this article.

\section{ORCID}

Olga Szulecka (iD https://orcid.org/0000-0001-9889-6703

\section{REFERENCES}

Adeyeye, S. A. O., Oyewole, O. B., Obadina, O., Adeniran, O. E., Oyedele, H. A., Olugbile, A., \& Omemu, A. M. (2016). Effect of smoking methods on microbial safety, polycyclic aromatic hydrocarbon, and heavy metal concentrations of traditional smoked fish from Lagos State, Nigeria. Journal of Culinary Science \& Technology, 14(2), 91-106. https://doi.org/10.1080/15428052.2015.1080644

Adeyeye, S. A. O., Oyewole, O. B., Obadina, A. O., Omemu, A. M., \& Omoniyi, S. A. (2017). Quality attributes, polycyclic aromatic hydrocarbon, and heavy metal profile of traditional drum-smoked Guinean barracuda fish from Lagos State, Nigeria. Journal of Aquatic Food Product Technology, 26(3), 296-307. https://doi.org/10.1080/10498 850.2016.1155191

Akpambang, V., Purcaro, G., Lajide, L., Amoo, I., Conte, L., \& Moret, S. (2009). Determination of polycyclic aromatic hydrocarbons (PAHs) in commonly consumed Nigerian smoked/grilled fish and meat. Food Additives \& Contaminants, 26(7), 1096-1103. https://doi. org/10.1080/02652030902855406

AOAC. (1990). Official methods of analysis of the association of official analytical chemistry (15th ed.). Arlington, VA: Association of Official Analytical Chemists.

Ariese, F., Kok, S. J., Verkaik, M., Gooijer, C., Velthorst, N. H., \& Hofstraat, J. W. (1993). Synchronous fluorescence spectrometry of fish bile: A rapid screening method for the biomonitoring of PAH exposure. Aquatic Toxicology, 26, 273-286. https://doi. org/10.1016/0166-445X(93)90034-X

Baryłko-Pikielna, N., \& Matuszewska, I. (2014). Sensoryczne badania żywności. Podstawy. Metody. Zastosowania. [Sensory analysis of food. Principles. Methods. Applications.] Kraków, Poland: Wydawnictwo Naukowe PTTŻ (in Polish).

Bykowski, P. J., Polak-Juszczak, L., Usydus, Z., Barska, I., Skrzyński, I., Malesa-Ciećwierz, M., Łądkowska, M. (2000). Badanierybmorskich i przetworówrybnych. [Study of marine fish and fish products.] In Raport z badańmonitoringowychnadjakościagleb, roślin, produktówrolniczych i spożywczych w 1999 r. [Monitoring report on the quality of soil, 
plants, agricultural products and food products for 1999]. Warszawa, Poland: The Ministry of Agriculture and Rural Development, Dom Wydawniczy Elipsa (in Polish).

CAC/RCP 68/2009. (2009). Code of practice for the reduction of contamination of food with polycyclic aromatic hydrocarbons (PAH) from smoking and direct drying processes. Retrieved from http://www.fao.org/ input/download/standards/11257/CXP_068e.pdf

Cardinal, M., Knockaert, C., Torrissen, O., Sigurgisladottir, S., Mørkøre, T., Thomassen, M., \& Vallet, J. L. (2001). Relation of smoking parameters to the yield, colour and sensory quality of smoked Atlantic salmon (Salmo salar). Food Research International, 34, 537-550. https://doi. org/10.1016/S0963-9969(01)00069-2

Duedahl-Olesen, L., Christensen, J. H., Højgård, A., Granby, K., \& TimmHeinrich, M. (2010). Influence of smoking parameters on the concentration of polycyclic aromatic hydrocarbons (PAHs) in Danish smoked fish. Food Additives \& Contaminants, 27(9), 1294-1305. https:// doi.org/10.1080/19440049.2010.487074

EC. (2006). Commission Regulation (EC) No 1881/2006 of 19 December 2006 setting maximum levels for certain contaminants in foodstuffs. Official Journal of the European Union, L364, 5-24 with later amendments.

EC. (2011). Commission Regulation (EU) No 835/2011 of 19 August 2011 amending Regulation (EC) No 1881/2006 as regards maximum levels for polycyclic aromatic hydrocarbons in foodstuffs. Official Journal of the European Union, L215, 4-8.

EFSA. (2008). Scientific opinion of the panel on contaminants in the food chain on a request from the European Commission on polycyclic aromatic hydrocarbons in food. EFSA Journal, 724, 1-114.

Essumang, D. K., Dodoo, D. K., \& Adjei, J. K. (2013). Effect of smoke generation sources and smoke curing duration on the levels of polycyclic aromatic hydrocarbon (PAH) in different suites of fish. Food and Chemical Toxicology, 58, 86-94. https://doi.org/10.1016/ j.fct.2013.04.014

EU. (2015). Commission Regulation (EU) 2015/1125 of 10 July 2015 amending Regulation (EC) No 1881/2006 as regards maximum levels for polycyclic aromatic hydrocarbons in Katsuobushi (dried bonito) and certain smoked Baltic herring. Official Journal of the European Union, L184, 7-10.

Gawęcka, J., \& Jędryka, T. (2001). Analiza sensoryczna. Wybrane metody i przykłady zastosowań. [Sensory analysis. Chosenmethods and applicationexamples]. Wydawnictwo Akademii Ekonomicznej w Poznaniu. Poznań (in Polish).

Hokkanen, M., Luhtasela, U., Kostamo, P., Ritvanen, T., Peltonen, K., \& Jestoi, M. (2018). Critical effects of smoking parameters on the levels of polycyclic aromatic hydrocarbons in traditionally smoked fish and meat products in Finland. Journal of Chemistry, 2018, 1-14. https:// doi.org/10.1155/2018/2160958

IARC. (2015). Agents Classified by the IARC Monographs, Vol. 1-112. Retrieved from https://monographs.iarc.fr/ENG/Classification/ ClassificationsAlphaOrder.pdf

Ledesma, E., Rendueles, M., \& Diaz, M. (2016). Contamination of meat products during smoking by polycyclic aromatic hydrocarbons: Processes and prevention. Food Control, 60, 64-87. https://doi. org/10.1016/j.foodcont.2015.07.016

Pettersen, K. (2015). SeafoodStudy. Opinie i perspektywy: Konsumpcja ryb wśród Polaków. [Opinions and perspectives: The consumption of fish among the Poles]. Retrieved from http://www.rybyznorwegii.pl/ content/view/full/105698 (in Polish).

Pöhlmann, M., Hitzel, A., Schwägele, F., Speer, K., \& Jira, W. (2013). Polycyclic aromatic hydrocarbons (PAH) and phenolic substances in smoked Frankfurter-type sausages depending on type of casing and fat content. Food Control, 31, 136-144. https://doi.org/10.1016/ j.foodcont.2012.09.030
Rainio, K., Linko, R. R., \& Routsila, L. (1986). Polycyclic aromatic hydrocarbons in mussel and fish from the Finnish archipelago sea. Bulletin of Environmental Contamination and Toxicology, 37, 337-343. https:// doi.org/10.1007/BF01607770

Roseiro, L. C., Gomes, A., \& Santos, C. (2011). Influence of processing in the prevalence of polycyclic aromatic hydrocarbons in a Portuguese traditional meat product. Food and Chemical Toxicology, 49, 1340-1345. https://doi.org/10.1016/j.fct.2011.03.017

Ruxton, C. H., Reed, S. C., Simpson, M. J., \& Millington, K. J. (2007). The health benefits of omega- 3 polyunsaturated fatty acids: A review of the evidence. Journal of Human Nutrition \& Dietetics, 20(3), 275-285.

SCF. (2002). Opinion of the scientific committee on food on the risks to human health of polycyclic aromatic hydrocarbons in food. Scientific Committee on Food (SCF). Retrieved from https://ec.europa.eu/food/ sites/food/files/safety/docs/sci-com_scf_out153_en.pdf

Stołyhwo, A., \& Sikorski, Z. E. (2005). Polycyclic aromatic hydrocarbons in smoked fish-A critical review. Food Chemistry, 91, 303-311. https://doi.org/10.1016/j.foodchem.2004.06.012

Szostak, S., \& Drożdż, J. (2015). Popyt na ryby i owoce morza. Przetwórstwo [The demand for fish and seafood. Processing]. RYNEK RYB stan i perspektywy, 23, 23-26 (in Polish).

Ünlüsayin, M., Süleyman, K., \& Gulyavuz, H. (2001). The determination of flesh productivity and protein components of some fish species after hot smoking. Journal of the Science of Food and Agriculture, 81, 661-664. https://doi.org/10.1002/jsfa.862

Usydus, Z., Szlinder-Richert, J., \& Adamczyk, M. (2009). Protein quality and amino acid profiles of fish products available in Poland. Food Chemistry, 112, 139-145. https://doi.org/10.1016/ j.foodchem.2008.05.050

Usydus, Z., Szlinder-Richert, J., Adamczyk, M., \& Szatkowska, U. (2011). Marine and farmed fish in the Polish market: Comparison of the nutritional value. Food Chemistry, 126, 78-84. https://doi.org/10.1016/ j.foodchem.2010.10.080

WHO. (2006). World Health Organization (WHO). Genova 2006. The joint FAO/WHO expert committee on food additives. JECFA. Evaluation of certain food contaminants. Sixty-fourth report of the joint FAO/WHO expert committee on food additives. WHO Technical Report Series, No 930, 61-79. Retrieved from http:// apps.who.int/iris/bitstream/10665/43258/1/WHO_TRS_930_ eng.pdf

U.S. EPA. (1993). Provisional guidance for quantitative risk assessment of polycyclic aromatic hydrocarbons. Washington, DC: Office of Research and Development. U.S. Environmental Protection Agency. https:// epa-prgs.ornl.gov/chemicals/help/documents/600R93089.pdf

Wilms, M. (2000). The developing of modern smokehouses-Ecological and economical aspects. Fleischwirtschaft International, 80, 4-5.

Wretling, S., Eriksson, A., Eskhult, G. A., \& Larsson, B. (2010). Polycyclic aromatic hydrocarbons (PAHs) in Swedish smoked meat and fish. Journal of Food Composition and Analysis, 23, 264-272. https://doi. org/10.1016/j.jfca.2009.10.003

Zachara, A., Gałkowska, D., \& Juszczak, L. (2017). Contamination of smoked meat and fish products from Polish market with polycyclic aromatic hydrocarbons. Food Control, 80, 45-51. https://doi. org/10.1016/j.foodcont.2017.04.024

How to cite this article: Malesa-Ciećwierz M, Szulecka O,

Adamczyk M. Polycyclic aromatic hydrocarbon contamination of Polish smoked fish: Assessment of dietary exposure. J Food Process Preserv. 2019;e13962. https://doi.org/10.1111/jfpp.13962 